\title{
Continuing Case Against Inter-Period Tax Allocation
}

Ron Colley, University of West Georgia, USA

Joseph Rue, Florida Gulf Coast University, USA

Ara Volkan, Florida Gulf Coast University, USA

\begin{abstract}
The annual and industry-based behavior of deferred tax balances is analyzed and the accounting theory and procedures required by the FASB are examined in the context of the unit problem. The unit problem involves the selection of the appropriate perspective (either individual or aggregate) for applying measurement and recognition conventions to phenomena of interest. From an individual event perspective, the FASB's conclusions regarding liability recognition are inconsistent with the definition of liabilities found in the Statement of Financial Accounting Concepts No. 6. In addition, the use of inconsistent perspectives by S109 creates disagreements with the FASB's position, where both the individual and aggregate perspectives are used simultaneously as the basis of the FASB's decisions. The impact of eliminating deferred taxes and adjusting the liability and stockholders equity balances on the debt-to-equity (DTE) ratio is computed for each year and 20 industries in the COMPUSTAT database (1997 - 2006). The change results in significant decreases in DTE each year and in all industries.
\end{abstract}

Keywords: Deferred taxes; accounting theory; debt-to-equity ratio; the unit problem; flow-through method

\section{INTRODUCTION}

¿ n 1992, the Financial Accounting Standards Board (FASB) issued Statement 109 (S109) to bring closure to accounting and financial reporting for deferred taxes (FASB, 1992). S109 requires companies to use the comprehensive tax allocation method and the asset/liability approach for all timing differences between income tax reporting on the financial statements and on the tax returns. The companies are required to use the current tax rate to accumulate the deferred tax assets and liabilities that result when the financial and tax bases of their assets and liabilities diverge. Then, the legal tax liability for the period is adjusted by the periodic changes in the deferred tax asset and liability balances, to arrive at the tax provision (tax expense). In addition, an allowance account is established if it is more likely than not that the deferred tax assets will not be realized. Finally, there are fairly complex rules concerning loss carry-forwards, tax planning strategies, classification of the asset and liability balances in the balance sheet, tax rate and status changes, business combinations, and disclosures in the footnotes.

The FASB has long struggled with the controversy of changing the reporting requirements for deferred taxes first promulgated in Accounting Principles Board (APB) Opinion \#11 (AICPA, 1967). The continuing controversies regarding the final pronouncement and the delays in implementing the final standard attested to the complexity of the issue. Currently, the FASB Interpretation No. 48 (FIN 48) concerning accounting for uncertain tax positions has caused much controversy (FASB, 2006). The impact of FIN 48 on tax reserves that are set up to mitigate challenges by tax authorities (Blouin at al, 2007) and auditing the balances of deferred tax and the allowance account balances (Alltizer, McAllister, and Jarnagin, 2008; Cowan and English, 2007) has been well documented. Accounting academics have generally supported the approach taken by FIN 48 (AAA, 2007) since its accounting and reporting standards recognize tax assets and liabilities based on the likelihood that they will be recognized by tax authorities. Finally, international standards concerning inter-period tax allocation and S109 have divergent accounting and reporting requirements that must be addressed to achieve convergence. 


\section{PURPOSE}

This study examines the theory underlying the current accounting and reporting standards for deferred taxes. We propose that the underlying issue in accounting for deferred taxes is the unit problem as presented by Devine (1985). In an earlier work, we observed the behavior of net deferred tax liability balances for 1,571 companies in 23 industries over a five-year period (1978-1982) and found that less than three percent of the companies experienced a decrease in their deferred tax balances. In this study we observe the net deferred tax liability balances of approximately 2,085 firms in 20 industries over a ten-year period (1997-2006). In addition, we illustrate the financial consequences of using the flow-through (where tax expanse is equal to the statutory tax liability) versus the asset-liability method of accounting for deferred taxes. We achieve this objective by computing the change in the debt-to-equity (DTE) ratios of the sample companies when net deferred tax balances are eliminated with corresponding adjustments in the total liability and stockholders equity balances.

\section{BACKGROUND AND THE UNIT PERSPECTIVE}

For decades, critics have raised several concerns about accounting for deferred taxes. They have criticized the: (1) inconsistent treatment of the deferred tax asset and liability (Wolk, Martin, and Nichols, 1989; Parks, 1988); (2) FASB's failure to allow for discounting of the deferred tax liability (Rayburn, 1987); (3) complexity of the accounting methods and their potential lack of usefulness (Colley, Rue, and Volkan, 2006; Bierman. 1990; Burton and Sack, 1989; Gregory, Petree, and Vitray, 1992); (4) failure of the FASB to deal with temporary differences that are permanently deferred (Jeter and Chancy, 1988); (5) potential negative impact of the requirements on stock options (Placid, Rue, and Volkan, 2008; Nichols and Betancourt, 2006); and (6) lack of relevance of deferred tax amounts under full recognition approach (both discounted and undiscounted) in predicting stock returns (Lev and Nissim, 2004), market value of firms (Guenther and Sansing, 2004), discounted value of asset-level reversals of deferred tax balances (Guenther and Sansing, 2004), and future profitability of firms in U.K. where partial recognition method was recently replaced with the S109 approach (Gordon and Joos, 2004). Many of these concerns have not been fully addressed by S109.

Income tax accounting controversies will not subside until the FASB reconsiders S109 and adequately addresses the unit problem. The unit problem involves the selection of either the individual perspective or the aggregate perspective for applying measurement and recognition conventions to the phenomenon of interest. The positions taken by both proponents and opponents of S109 are affected by whether one views income tax accounting as an issue of accounting for individual events or accounting for aggregate activity. While the FASB generally views deferred taxes from an individual perspective, the nature of taxation is an aggregate phenomenon.

\section{The Unit Problem}

The unit problem addresses the selection of appropriate attributes for characterizing the event for which one wishes to account. The accounting process involves the identification, grouping and measurement of what are believed to be relatively homogeneous events. If events are not strictly homogeneous problems arise in selecting attributes of the group or class portrayed by the accounting process (Colley, Rue, and Volkan, 2004; Rue and Volkan, 1997). Some may take a specific or individual perspective that examines the attributes of one member of the group and assumes that those attributes may be generalized to the other members. Others may take an aggregate perspective that attempts to identify attributes relevant to the accounting process by examining the behavior of the group taken as a whole rather than focusing on individual members.

For example, warranty obligations qualify as a liability only from an aggregate perspective. It is unlikely that a warranty obligation will arise from a given sales transaction (individual perspective), since the probability that a particular product is defective is small. However, experience with aggregate sales and related warranties suggests that some sales will require warranty claims. Thus, the existence of a warranty obligation makes sense only when the evaluation is made from an aggregate perspective. Another area where the FASB took an aggregate perspective in developing accounting standards is financial reporting for post-employment benefits. We argue that the aggregate perspective is applicable to many other financial statement items, including deferred taxes. 


\section{S109 and IAS 12 - Divergence on the Individual Event Perspective}

While not explicitly stated, the FASB's view of the income tax accounting issue generally requires that an individual event perspective be taken. The FASB's position is that tax consequences of an individual event are separable from aggregate taxable income. S109 indicates that individual temporary differences become taxable or deductible when the related asset is recovered or the related liability is settled (FASB, 1992, Summary). The FASB's discussion of the basis for their conclusions also clearly indicates the individual event perspective that they take. For example, in response to advocates of partial allocation (an aggregate perspective), the FASB states that the deferred tax consequences of a depreciation difference for a particular depreciable asset ordinarily will result in a sacrifice in future years. There will be a future sacrifice because a new individual difference resulting in a taxable amount will be used up to offset an old, reversing taxable amount.

Based upon this individual event perspective, S109 required the adoption of the asset-liability approach of accounting for inter-period income tax allocation. This line of reasoning assumes that the tax consequences of earning income or incurring losses or expenses in future years are not anticipated for purposes of recognition and measurement of a deferred tax liability or asset. Since this view is not defensible in many situations, S109 modifies this requirement in case of deferred tax assets by considering future events to assess the likelihood that future tax consequences have been affected by events recognized in the current financial statements (FASB, 1992, par. 6). Thus, the FASB creates an inconsistency in accounting for deferred tax assets and deferred tax liabilities by considering future events to promulgate accounting procedures for the former but refusing to do the same to promulgate accounting standards for the latter.

On the other hand, International Accounting Standard 12 (IASB, 1996) recognizes that it is difficult for firms to determine the amount of future income tax that may result from temporary differences. The standard requires deferred tax procedures be used and assets and liabilities be recognized except for those temporary differences where future reversals are not probable. Consequently, a large portion of deferred tax liabilities may not be recorded since most timing differences related to depreciation will not reverse in the future because of the capital replacement policies most firms employ (see Table 1 below for an illustration). Thus, the policies adopted by the FASB and IASB to achieve global convergence and harmonization of accounting standards present an opportunity for the critical review of the asset-liability approach for deferred taxes and the adoption of a different (e.g., the flow-through) method.

\section{ALLOCATION VERSUS NON-ALLOCATION - THEORETICAL ISSUES}

\section{Taxes - Expenses or Redistribution of Wealth?}

Deferred tax accounting is based on the concept that income taxes are expenses. We contend that the question of whether to allocate taxes between periods depends on whether the income tax provision for a period is an expense or simply a redistribution of wealth. Although it could be argued that the expenses can be allocated, income distributions should not be allocated among periods. Income distributions should be charged to the period in which they occur. In other words, the tax provision should equal the taxes payable if taxes are income distributions. Thus, business should only be concerned with recognizing income taxes in the period where the related taxable income occurs. Taxes are a function of government fiscal and monetary policies, and they are not functionally related to financial reporting of companies. While we believe that taxes are redistribution of wealth, in this paper we will yield to the prevailing theory that recognizes taxes as expenses (Rue and Volkan, 1985).

\section{Challenging the Myth of Inter-Period Allocation}

Even when one agrees that taxes are expenses of doing business, one can maintain that the amount of income tax expense reported on a company's income statement should be the same as the income taxes payable for the accounting period as determined by the income tax return. Schroeder, Clark, and Cathey (2001, pp. 358-359) summarize the arguments advanced by both the advocates and opponents of allocation into several categories: 1) the nature of expenses and liabilities, 2) the unit perspective to be applied to recognition and measurement, and 3) assessment of future cash flows. 
Non-allocation advocates take positions that address issues embedded in all three categories. First, they contend that income taxes result only from taxable income. Whether or not the company has accounting income is irrelevant and matching income taxes with accounting income does not provide relevant information. The allocation of income taxes in a manner similar to other expenses is not relevant. While expenses measure the cost of generating revenue, income taxes generate no revenues. They are neither incurred in anticipation of future benefits nor are they expirations of costs.

Non-allocation advocates point out that income taxes are not levied on individual items of revenue and expense. Therefore, there can be no temporary differences related to these items. In addition, inter-period tax allocation hides an economic difference between a company that employs tax strategies that reduce current tax payments and one that does not. Reporting a company's income tax expense at the amount paid or currently payable should provide more useful information in predicting a company's future cash outflows.

Finally, those who favor non-allocation argue that income tax allocation entails a forecast of future profits. To incorporate such forecasts into accounting measures is inconsistent with the principles of accounting. There is no present obligation for the potential or future tax consequences of past transactions because there is no contract (as it is the case with employee benefits and leases) and no legal liability to pay taxes until an actual tax return is prepared. Moreover, the accounting processes required by S109 are too costly for the purported benefits.

Inter-period tax allocation advocates also address similar issues, but arrive at conclusions that are completely opposite to those of non-allocation advocates. First, since taxes result from the existence of transactions and events, tax expense should be based on the results of the transactions or events that are included in financial statements and should involve the same accrual, deferral, and estimation concepts that are applied to other expenses. In addition, since the differences between the timing of individual revenues and expenses result in temporary differences that will reverse in the future, inter-period tax allocation makes a company's net income a more useful measure of its long-term earning power.

Third, non-allocation of a company's income tax expense hinders the prediction of its future cash flows. For instance, a company's future cash inflows from installment sales collection would usually be offset by related cash outflows for taxes. Finally, since a company is a going concern and temporary differences are associated with future tax consequences, income taxes resulting from individual events that are currently deferred will eventually be paid as reversals of originating differences that provide present tax savings will result in future taxable incomes and tax payments. Thus, deferred tax liabilities are similar to other contingent liabilities.

In the following sections we will challenge the arguments presented by the advocates of inter-period tax allocation using the unit perspective and the definitions of liabilities and expenses in FASB's concept statements.

\section{THE QUESTION OF ASSET - LIABILITY RECOGNITION}

While the arguments presented in this section also apply to deferred tax assets, for the sake of brevity we address only the liability issue. In the FASB's view, the deferred tax liability meets the Statement of Financial Accounting Concepts No. 6 (SFAC 6) definition of a liability that is the probable future sacrifice of economic benefits that arise from present obligations of a particular entity to transfer assets or provide services to other entities in the future as a result of past transactions or events (FASB, 1985, par. 35). In support of its conclusions in S109, the FASB argues that:

1. Temporary differences will become taxable amounts in future years as a result of events whose occurrence is already inherently assumed in an enterprise's statement of financial position for the current year,

2. No other future events need occur,

3. The enterprise might be able to delay settlement of a tax obligation by delaying the events that give rise to taxable amounts. However, a contention that those events will never occur would contradict assumptions inherent in the statement of financial position, and

4. Tax obligations are incurred when temporary differences originate. 
It can be demonstrated that this conclusion is not supported by the FASB's implicit individual event perspective. If one takes an individual event perspective, the characteristics of a liability resulting from depreciating an individual asset using different depreciation methods are present only if the temporary differences between taxable income and financial statement income that result in future net taxable amounts can be recovered through the use of sufficient future taxable income. However, these timing differences may reverse when the firm has no taxable income or incurred a loss. Since taxes are not paid, there is no future economic sacrifice.

From an individual event perspective, the resource transfer is dependent upon future events, namely future income. Further, the sacrifices of economic benefits arising from present obligations of an entity disappear or are significantly reduced if a depreciable asset is sold during its useful life for an amount less than its book value. Liability recognition is warranted only if the asset is held to the end of its useful life. Liability recognition resulting from an individual transaction depends upon aggregate future events, that is, future operational decisions regarding depreciable assets.

Another question is whether a present obligation exists. Unlike all other liabilities recognized for financial reporting purposes, there is no explicit or implicit contract between the reporting entity and the creditor. At any point in time in the life of the entity, the government does not have a claim to the entity's assets for the deferred tax liability. The only time the claim arises is in the future when sufficient taxable income is reported. While the recovery of the asset through use or sale has a high probability of occurrence in a going concern, the incidence of tax depends on the occurrence of future events that together determine whether taxable income exists.

The third aspect of the SFAC 6 definition is that future sacrifices are a result of past transactions or events. While depreciation is described as an internal event (FASB, 1992, par. 138), temporary differences between taxable income and financial statement income are not caused by the event of depreciation. The differences occur because of the use of alternative methods of depreciation. Since the law allows alternative allocation schemes, the resulting taxable income and accounting income are caused by different allocation methods and estimates of residual value. They are not the result of past transaction or events since estimates of useful life and residual values must reflect future usefulness. In addition, if the Federal government lowers the tax rate a portion of the deferred tax balances needs to be reduced.

Finally, the long-term deferred tax liability is the only non-current liability that is exempt from discounting, violating the FASB standards and concepts related to the measurement of liabilities and the requirements to use present values. S109 (par. 199) essentially declines to address this issue. If the trends in the size and nature of deferred tax balances were examined to determine appropriate discount periods, the process of discounting could reduce the reported deferred tax amounts to zero or to a very small number. One of the arguments against the use of discounting is that since the government does not recognize the existence of a liability and there are no other contractual counter-parties, the discount rate is zero (Rayburn, 1987). However, this argument serves just the opposite of its intended purpose, strengthening our contention that flow-through approach should be used in accounting for taxes.

\section{DEFERRED TAX LIABILITY BALANCES - AN AGGREGATE VIEW}

The following example illustrates how the growth in deferred tax liability supports the aggregate events perspective. Assume that a company acquires a machine with a residual value of $\$ 80,000$, a useful life of 5 years, and a cost of $\$ 1,000,000$, every year. In addition, the company uses double declining balance depreciation for tax purposes and straight-line depreciation for financial reporting. The tax rate is $34 \%$. The effect of these assumptions on the deferred tax liability is illustrated in Table 1.

Table 1 shows that the liability reaches a constant level after five years. The resulting tax liability will not be paid unless the company fails to replace a machine as it is worn out. On the other hand, the deferred tax liability is likely to increase as the company expands and adds more machines. Further, if it is assumed that the firm is holding its productive capacity stable, it will continue to acquire new machines. These additional machines will probably cost more and lead to an increased deferred tax liability. The liability is reduced only if the firm 
discontinues its capital investment in new machinery and starts to curtail operations. However, there are very few industries where such an outcome is probable at the aggregate level.

As discussed previously, a liability is defined as a situation requiring future sacrifice of assets resulting from an unavoidable obligation. If the deferred tax process results from an individual difference, the deferred tax liability declines in those years where the tax payment exceeds the tax expense. Then, an argument can be made, as the FASB has, that the deferred tax liability represents a future sacrifice. However, as it is demonstrated above, liability recognition for individual differences is dependent upon future occurrence of aggregate income or loss, which clearly violates one of the liability recognition criteria.

Table 1 - Illustration of Growth in Aggregate Deferred Tax Liability

\begin{tabular}{lccccc}
\hline & Year 1 & Year 2 & Year 3 & Year 4 & Year 5 \\
\hline & & & & & \\
Increase Due to Purchase in Current Year (t) & 73.4 & 73.4 & 73.4 & 73.4 & 73.4 \\
Increase Due to Purchase in Prior Year (t-1) & & 19.0 & 19.0 & 19.0 & 19.0 \\
Decrease Due to Reversal From Year (t-2) & & & $(13.6)$ & $(13.6)$ & $(13.6)$ \\
Decrease Due to Reversal From Year (t-3) & & & & $(33.2)$ & $(33.2)$ \\
Decrease Due to Reversal From Year (t-4) & 73.4 & 92.4 & 78.8 & 45.6 & $(45.6)$ \\
Total Increase & 73.4 & 165.8 & 244.6 & 290.2 & -- \\
Liability Balance & & & & & 290.2
\end{tabular}

If on the other hand, one views the deferred tax process from an aggregate perspective, considering the joint effects of many differences, the deferred asset or liability balances may grow and remain on the company's balance sheet indefinitely. Although the item may represent a future sacrifice of assets, the sacrifice will be avoided indefinitely if the company continues to act in ways that maintain the aforementioned equilibrium. Accordingly, many deferred tax items do not satisfy the liability definition if viewed in the aggregate since company policy on asset purchases can postpone aggregate reversals. Since net deferred tax balances continue to grow over time, companies must have a policy of acquiring depreciable assets on a continuing basis to stop deferrals from reversing.

\section{THE CHOICE OF AN ACCOUNTING PERSPECTIVE: THE UNIT PROBLEM REVISITED}

The discussion presented above indicates that the choice of perspective from which to evaluate accounting phenomena should be based on our understanding of their underlying nature. If the phenomena are seen as members of a group where each member's range of potential behavior has impact only to the extent that it contributes to the behavior of the group, then the aggregate perspective is suggested. Alternatively, if this range of potential is fully realizable for each phenomenon under normal conditions, then an individual perspective is suggested.

The act of taxation is an aggregate phenomenon and the tax to be paid in a period is based on taxable income of the period. Individual transactions or events are not taxed. Only aggregate financial results lead to a transfer of funds to various governments. Recognizing tax expenses, assets, and liabilities on individual events is not representationally faithful. The FASB has acknowledged the aggregate nature of income tax determination by allowing companies to utilize tax-planning strategies when considering the future years' effects of temporary differences. Thus, the FASB recognized that one objective of corporate tax policies is to minimize the annual tax obligations and that it is possible that all or a portion of a deferred tax obligation will not be paid.

The obvious conclusion is that the FASB's deferred tax requirements cannot be supported from either an individual event perspective or from an aggregate perspective. The FASB should abandon the asset/liability method of accounting for income taxes. Therefore, the taxes payable should equal tax expense. If the effect of timing differences of tax deferrals needs to be disclosed, the existing standards for contingencies may be used to report the amount in the footnotes to financial statements. 


\section{METHODOLOGY}

If net deferred tax positions were no longer reported on the balance sheet, and the flow-through method of accounting for income taxes was used, what impact would it have on a company's financial position? To answer this question, we study approximately 2,085 companies reporting a deferred tax position from 1997 to 2006 in 20 industries. We use the deferred tax balances for the selected firms reported in the CS Active and CS Research data sets in the Research Insight COMPUSTAT database. The COMPUSTAT variable used is TXDB, representing the net accumulated tax deferrals on the balance sheet due to timing differences between the reporting of revenues and expenses for financial reporting and tax purposes, including the effects of investment tax credits. Since this variable is not available for banks and insurance companies, these firms are excluded from our analyses. Our study focuses on the change in the debt-to-equity (DTE) ratio assuming that net deferred tax assets and liabilities are not reported on the balance sheet. Of course, many financial ratios are affected if the flow-through method is used, but the DTE ratio is a significant measure of a company's risk and indicates the ability of a company to access capital markets.

The first step in our study is to adjust the balance sheets of companies by eliminating the net deferred tax position represented by the COMPUSTAT data item TXDB that sums all deferred tax asset and liability amounts reported in the balance sheet. The analysis of the database shows that all net deferred tax positions have credit balances. We deduct the TXDB from total liabilities and add it to owners' equity because if the deferred taxes had not been recorded, cumulative income from previous years would have been higher. Next, we determine the DTE ratio under the current method (DTED) and the flow-through method advocated in this paper (DTEF) for each company. Each year, DTEs of twenty (20) or higher are eliminated to remove outliers. In addition, companies with negative total equity in a given year are excluded from the analyses carried out in that year. To observe the behavior pattern of the TXDB balances, the net deferred tax is divided by total assets to remove size bias.

The statistical analysis is carried out at two levels: all observations for the entire sample each year and each industry each year. In addition, we compute overall averages for each industry and the entire sample over the ten-year period. To improve clarity and reduce excessive detail, Tables 2 and 3 show only the overall average results. We test for differences of means in this study to determine significance. The test statistic is the ratio of the difference of the means of the DTE ratios to the standard error and one-tailed t-test is used since we expect the DTE ratios to decline. When the sample sizes are small (Personal Services for all ten years and in three other occasions 13 out of 400-plus tests), the nonparametric Wilcoxon Signed Ranks (WSR) test is used. For the differences between DTED and DTEF and the ratio of TXDB to total assets, weighted averages (WA) are computed to remove the bias introduced by having different number of companies in different industries and in different years.

\section{RESULTS}

\section{Data Characteristics}

The number of raw observations was 21,964. After adjusting for DTE ratios over 20 and negative equity amounts, 20,849 observations were used, a five percent decrease. The number of observations in a given industry from one annual period to the next increased when new firms were added and decreased as existing firms merged or went out of business.

\section{Annual Results for All Industries}

Table 2 presents the weighted average results of our study for the 1997-2006 period based on the entire sample and each year. The number of observation included in the analysis range from a low of 1846 in 2002 to a high of 2,470 in 1997. The weighted average annual ratio of net deferred tax balances to total assets remains stable around 5.1 percent for the overall sample, moving within a range of 4.8 in 2000 to 5.4 percent in 1997. Thus, the overall behavior of the ratio of deferred tax balances to total assets, while showing small fluctuations from year to year, stays remarkably stable, matching the pattern demonstrated in the Table 1 . Since it is logical to assume that total assets grow over time, companies must have a policy of acquiring assets on a continuing basis to stop deferrals from reversing and keeping net deferred tax balances at a level commensurate with the growth in total assets. 
While the average DTED ratio for the overall sample for the 1997-2006 period ranges from a low of 1.66 in 2006 to a high of 2.00 in 2000, the average DEF ranges from a low of 1.32 in 1997 to a high of 1.55 in 2000 . The DTE ratios decline a weighted average of 22.4 percent when the flow-through method is used, but remain within the range of 21.1 percent in 1999 to 23.9 in 2004. In addition, both the t-tests and the WSR tests show that the declines are statistically significant for the total sample and each year with a 99.9 confidence level or better.

\section{Industry Results for All Years}

Table 2 - Weighted Average Total Sample and Annual Results for All Industries Combined

\begin{tabular}{lccccll}
\hline Year & $\begin{array}{c}\text { Total } \\
\text { Number of } \\
\text { Observations }\end{array}$ & DTED & DTEF & DIFF & $\begin{array}{l}\text { Percent } \\
\text { Decrease } \\
\text { in DTE (*) }\end{array}$ & $\begin{array}{l}\text { Percent of } \\
\text { TXDB to } \\
\text { Total Assets }\end{array}$ \\
\hline All Years & 20,849 & 1.81 & 1.40 & .41 & $22.4 \%$ & $5.1 \%$ \\
$\mathbf{1 9 9 7}$ & 2,470 & 1.68 & 1.32 & .36 & 21.2 & 5.4 \\
$\mathbf{1 9 9 8}$ & 2,340 & 1.78 & 1.42 & .36 & 20.4 & 5.2 \\
$\mathbf{1 9 9 9}$ & 2,236 & 1.86 & 1.47 & .39 & 21.1 & 5.0 \\
$\mathbf{2 0 0 0}$ & 2,122 & 2.00 & 1.55 & .45 & 22.6 & 4.8 \\
$\mathbf{2 0 0 1}$ & 1,943 & 1.93 & 1.49 & .44 & 22.9 & 5.0 \\
$\mathbf{2 0 0 2}$ & 1,846 & 1.85 & 1.42 & .43 & 23.3 & 5.2 \\
$\mathbf{2 0 0 3}$ & 1,920 & 1.81 & 1.38 & .43 & 23.6 & 5.0 \\
$\mathbf{2 0 0 4}$ & 2,024 & 1.80 & 1.37 & .43 & 23.9 & 4.9 \\
$\mathbf{2 0 0 5}$ & 2,017 & 1.73 & 1.34 & .39 & 22.7 & 5.0 \\
$\mathbf{2 0 0 6}$ & 1,931 & 1.66 & 1.29 & .37 & 22.3 & 5.2 \\
\hline
\end{tabular}

(*) All decreases are statistically significant with $\mathrm{p}<.001$

Table 3 - Weighted Average Total Sample and Industry Results for 1997-2006

\begin{tabular}{|c|c|c|c|c|c|c|}
\hline Industry & $\begin{array}{c}\text { Total } \\
\text { Number of } \\
\text { Observations } \\
(*)\end{array}$ & DTED & DTEF & DIFF & $\begin{array}{l}\text { Percent } \\
\text { Decrease } \\
\text { in DTE }(* *)\end{array}$ & $\begin{array}{l}\text { Percent of } \\
\text { TXDB } \\
\text { to Assets }\end{array}$ \\
\hline All Industries & 20,849 & 1.81 & 1.40 & .41 & $22.4 \%$ & $5.1 \%$ \\
\hline Chemicals & 329 & 2.45 & 1.82 & .63 & 19.0 & 4.6 \\
\hline Construction & 269 & 2.38 & 2.08 & .30 & 9.7 & 2.3 \\
\hline Drugs \& Med. Eq. & 732 & 1.03 & 0.88 & .15 & 14.5 & 3.2 \\
\hline Electronics & 941 & 1.05 & 0.92 & .13 & 10.3 & 2.0 \\
\hline Food Products & 1,073 & 2.01 & 1.52 & .49 & 18.8 & 4.5 \\
\hline Household Goods & 264 & 1.98 & 1.39 & .59 & 12.4 & 3.1 \\
\hline Machinery & 5,201 & 1.42 & 1.22 & .20 & 10.9 & 2.3 \\
\hline Mining & 413 & 1.20 & 0.85 & .35 & 29.8 & 6.9 \\
\hline Motor Vehicles & 501 & 2.88 & 2.39 & .49 & 12.5 & 2.4 \\
\hline Personal Services & 120 & 2.78 & 1.90 & .88 & 19.1 & 3.9 \\
\hline Petroleum \& Nat. Gas & 1,431 & 1.38 & 0.99 & .39 & 28.4 & 7.7 \\
\hline Printing and Publishing & 487 & 2.06 & 1.54 & .52 & 19.9 & 4.9 \\
\hline Retailers & 1,709 & 1.66 & 1.43 & .23 & 10.8 & 2.5 \\
\hline Rubber \& Plastics & 328 & 2.34 & 1.90 & .44 & 14.9 & 3.3 \\
\hline Steel & 1,100 & 1.75 & 1.45 & .30 & 16.2 & 4.0 \\
\hline Textiles & 470 & 1.62 & 1.33 & .29 & 14.5 & 3.5 \\
\hline Transportation & 1,172 & 2.18 & 1.59 & .59 & 28.7 & 7.9 \\
\hline Utilities & 2,365 & 2.71 & 1.66 & 1.05 & 37.4 & 10.9 \\
\hline Wholesalers & 998 & 2.06 & 1.75 & .31 & 12.3 & 3.0 \\
\hline Wood \& Paper & 946 & 2.09 & 1.63 & .46 & 19.3 & 5.0 \\
\hline
\end{tabular}

(*) The average number of firms in each industry each year is one-tenth of this number

(**) All decreases are statistically significant with $\mathrm{p}<.001$ 
Table 3 presents the weighted average results of our study for the 1997-2006 period based on the entire sample and each industry. The number of observations included in the analysis ranged from a low of 120 in Personal Services industry to a high of 5,201 in Machinery. The average annual ratio of net deferred tax balances to total assets ranged from a low of 2.0 percent in Electronics to a high of 10.9 percent in Utilities. As expected, this ratio is quite high in Mining, Petroleum and Natural Gas, and Transportation. The low ratio of deferred tax balances to total assets in the Construction industry can be explained by the required use of percentage-of completion method for both accounting and tax reporting purposes. While the annual results for each industry are not shown separately, we can report that the year to year change in the ratio of net deferred tax balances to total assets in each industry is minimal, except in Mining, Petroleum and natural gas, and Printing and publishing.

While the average DTED ratio for the 20 industries ranges from a low of 1.03 in Drugs \& Medical Equipment to a high of 2.88 in Motor Vehicles, the average DTEF ranges from a low of 0.85 in Mining to a high of 2.39 in Motor Vehicles. Overall, the DTE ratio declined an average of 22.4 percent when the flow-through method was used. In addition, both the one-tailed t-test and the WSR tests show that the decreases in the DTE ratios are statistically significant for the total sample and in each industry with a 99.9 confidence level or better.

Thus, the implementation of the flow-through method will result in significant changes in a key ratio that is used in the financial evaluation of most companies. Conversely, the debt-to-equity ratios used at present in the financial evaluation of companies are flawed because the net deferred tax balances are included in liabilities, when it is clear that these accounts do not meet the liability criteria specified in accounting theory.

\section{CONCLUSIONS}

The current reporting requirements for deferred taxes are too complex and costly to apply. The everincreasing net deferred tax liability position for many firms does not appear to be reversing, and questions concerning whether taxes are an expense and whether the required method of accounting for deferred taxes is helpful in assessing future cash flows are still not resolved. This paper argues that the simultaneous use of incompatible unit perspectives by the FASB in S109 is the basis of the disagreements most critics have with the FASB's positions. The FASB adopted both individual and aggregate event perspectives, thus arguing both sides of the coin simultaneously and drawing insupportable conclusions regarding the recognition of liabilities and assets. This study concludes that income taxation is an aggregate phenomenon and an aggregate perspective is required, making the flow-through method of accounting the obvious choice.

The flow-through method of accounting for taxes results in significant decreases in the debt-to-equity ratio for most firms, improving their financial position. The flow-through method represents a logical approach in accounting for taxes as long as taxation is viewed as a transaction occurring between the private and public sectors. That is, taxation is the act of transferring a portion of the periodic increase in an entity's net worth (computed using the tax law) to a government entity for the privilege of conducting business in that government's jurisdiction. This method results in the equality of the tax provision for a period to the required cash outflow for taxes for that period, and deferred tax assets and liabilities are eliminated.

Therefore, deferred taxes do not meet the FASB's definition of a liability and do not belong on the balance sheet. At best, they represent contingencies since most firms have tax policies that allow them to continue deferring taxes at the aggregate level indefinitely making it probable that temporary difference will not reverse in the foreseeable future. Where the reversal of some deferred taxes is probable, it is appropriate to report those amounts in the financial statements with the remaining balances that may possibly reverse being disclosed in the footnotes. In this manner, global convergence and harmonization of accounting for inter-period tax allocation will be achieved.

\section{SUGGESTIONS FOR FUTURE RESEARCH}

Future research can examine the impact of using the flow-through method of income tax accounting in different industries. Also, the impact of using this method on samples of companies categorized by size may be of interest. In addition, the economic consequences of this accounting change should be analyzed by observing its 
impact on companies that persist during the entire time period examined. Finally, it will be interesting to see if the adoption of this accounting change ensures the consideration of the unit problem during IASB and FASB deliberations as they try to harmonize deferred tax accounting to achieve convergence in this critical accounting area.

The data underlying the empirical tests are available from the COMPUSTAT. Individual industry statistics for 10 years and for the entire sample is available from the authors and readers with comments or questions are encouraged to contact the authors via e-mail.

\section{ACKNOWLEDGENTS}

Authors acknowledge the support provided by the University of West Georgia research assistant Tony Malik whose efforts were invaluable in the completion of this study.

\section{AUTHOR INFORMATION}

Joseph C. Rue is a professor of accounting at Florida Gulf Coast University. He has previously taught at Syracuse University, Penn State and St Bonaventure University. He is CPA and received his PhD from the Pennsylvania State University in 1979. His research interest is in financial accounting. Recent publications have focused on accounting for stock options and deferred taxes. He is married and has four grown children and seven grandchildren. He lives in Estero, Florida.

Ara G. Volkan is the Chair of the Accounting and Finance Department at Florida Gulf Coast University. He is an Eminent Scholar and Moorings Park Chair of Managerial Accounting. He received his Ph. D. in accounting from the University of Alabama in 1979 and is a Florida CPA (1989). He taught at Syracuse University (1979-1985) and at University of South Alabama (1986-1989). Next, he chaired the Accounting and Finance Department at University of West Georgia (1989-2003) and was Interim Dean at the Richards College of Business (2003-2004). He is a member of many academic and professional organizations. He has authored numerous articles in academic and professional accounting journals and in other business outlets.

Ron Colley is the Chair of the Department of Accounting and Finance at the University of West Georgia. He is a CPA and received a Ph.D. from Georgia State University in 1986 and a Master of Accounting from the University of South Florida in 1980. He was previously on the faculty at the University of South Alabama (1985-1989).

\section{REFERENCES}

1. Accounting Principles Board, Opinion No. 11: Accounting For Income Taxes. New York, NY: AICPA, 1967.

2. Alltizer, R., B. McAllister, and B. Jarnagin, FIN 48: Accounting and Auditing Implications, The CPA Journal (August 2008), pp. 44-47.

3. American Accounting Association's Financial Accounting Standards Committee, A Response to the FASB ED on Accounting for Uncertain Tax Positions: An Interpretation of S109, Accounting Horizons (March 2007), pp. 103-112.

4. Bierman, H, One More Reason to Revise Statement No. 96, Accounting Horizons (July 1990), pp. 42-46.

5. Blouin, J., C. Gleason, L. Mills, and S. Sikes, What Can We Learn About Uncertain Tax Benefits from FIN 48? National Tax Journal (September 2007), pp. 521-535.

6. Burton, J., and R. Sack, Tax Allocation: Time for a Fundamental Change, Accounting Horizons (July 1989), pp. 110-112.

7. Colley, R., J. Rue, and A. Volkan, The Myth of Inter-Period Allocation of Deferred Taxes: Industry-Based Analyses, The Journal of American Academy of Business, Cambridge (March 2006), pp. 1-8.

8. Colley, R., J. Rue, and A. Volkan, Deferred Taxes Revisited, Journal of Business and Economic Research (August 2004), pp. 13-24.

9. Cowan, M., and T. English, The Challenge of Transparency in the Corporate Tax Departments, The CPA Journal (October 2007), pp. 42-49. 
10. Devine, C., The Unit Problem, Essays in Accounting Theory: Volume II, Sarasota, FL: American Accounting Association, 1985.

11. Financial Accounting Standards Board, SFAC 6: Elements of Financial Statements, Norwalk, CT: FASB, 1985.

12. Financial Accounting Standards Board, FAS 109 - Accounting for Income Taxes, Norwalk, CT: FASB, 1992.

13. Gordon, E., and P. Joos, Unrecognized Deferred Taxes: Evidence from the U.K., The Accounting Review (January 2004), pp. 97-124.

14. Gregory, G., T. Petree, and R. Vitray, FASB 109: Planning for Implementation and Beyond, Journal of Accountancy (June 1992), pp. 44-50.

15. Guenther, D., and R. Sansing, The Valuation Relevance of Reversing Deferred Tax Liabilities, The Accounting Review (April 2004), pp. 437-451.

16. International Accounting Standards Board. IAS 12 -Income Taxes, London: United Kingdom, 1996.

17. Jeter, D., and P. Chancy, A Financial Statement Analysis Approach to Deferred Taxes, Accounting Horizons (December 1988), pp. 41-49.

18. Lev, B., and N. Doron, Taxable Income, Future Earnings, and Equity Values, The Accounting Review (October 2004), pp. 1039-1074.

19. Magee, R., Accounting for Income Taxes, Montvale, NJ: Institute of Management Accountants, 1984.

20. Nichols, N., and L. Betancourt, Options and the Deferred Tax Bite, Journal of Accountancy (March 2006), pp. 71-75.

21. Parks, J., A Guide to FASB's Overhaul of Income Tax Accounting, Journal of Accountancy (April 1988), pp. 24-34.

22. Placid, R., J. Rue, and A. Volkan, GAAP/TAX Differences in Accounting for Nonqualified Employee Stock Options: The Gathering Storm, The Journal of Applied Business Research (Summer 2008), pp. 5361.

23. Rayburn, F., Discounting of Deferred Income Taxes: An Argument for Reconsideration, Accounting Horizons (March 1987), pp. 43-49.

24. Rue, J., and A. Volkan, The Income Tax Accounting Controversy: A Matter of Perspective, The Journal of Applied Business Research (Fall 1997), pp. 107-117.

25. Rue, J., and A. Volkan, The Case Against Deferred Taxes, Management Accounting (March 1985), pp. 3035.

26. Schroeder, R., M. Clark, and J. Cathey, Financial Accounting Theory and Analysis, $7^{\text {th }}$ ed., New York, NY: John Wiley and Sons, 2001.

27. Wolk, H., D. Martin, and V. Nichols, Statement of Financial Accounting Standards No. 96: Some Theoretical Problems, Accounting Horizons (July 1989), pp. 1-5. 
NOTES 